\title{
A GUIDE TO UNITED KINGDOM AND EUROPEAN COMMUNITY COMPETITION POLICY
}


Also by Nick Gardner

DECADE OF DISCONTENT 


\section{A Guide to United Kingdom and European Community Competition Policy}

Nick Gardner

Palgrave Macmillan 
DOI 10.1007/978-1-349-10782-7

(C) Nick Gardner 1990

Softcover reprint of the hardcover 1st edition 1990

All rights reserved. For information, write:

Scholarly and Reference Division,

St. Martin's Press, Inc., 175 Fifth Avenue,

New York, N.Y. 10010

First published in the United States of America in 1990

ISBN 978-0-312-04516-6

Library of Congress Cataloging-in-Publication Data

Gardner, Nick.

A guide to United Kingdom and European Community competition policy/ Nick Gardner.

p. $\mathrm{cm}$.

Includes bibliographical references.

ISBN 978-0-312-04516-6

1. Industry and state-Great Britain. 2. Anti-trust law-Great

Britain. 3. Competition-Great Britain. 4. Industry and state-

-European Economic Community countries. 5. Anti-trust law-European

Economic Community countries. 6. Competition-European Economic

Community countries. I. Competition policy. II. title.

HD3616.G73G37 1990

$338.941-\mathrm{dc} 20$ 
To my family 


\section{Contents}

List of Tables $\quad$ x

Preface $\quad$ xi

\section{PART I THE FRAMEWORK OF COMPETITION POLICY}

1 Ideas and Their Implementation
A Introduction
B The economic rationale
C Objectives and their implementation 12
D The US approach 18
E The European Community approach 22
F The British approach 23

2 The Legislative Framework
A Introduction
B Concerted restrictive practices $\quad 26$
C Abuse of a dominant position 32
D Restrictive practices under the Competition Act, and general references under the Fair Trading Act 35
E Restrictive labour practices 36
F Mergers 37
G Patents and copyrights 39
$\mathrm{H}$ State enterprises and public utilities 42

3 Regulatory Institutions and Procedures
A Introduction
B The regulatory institutions of the European Community and their procedures
C The Office of Fair Trading
D The Monopolies and Mergers Commission 65
E The Restrictive Practices Court $\quad 72$
F The Secretary of State $\quad 73$
G The Civil Courts 77
H Organisational Interactions $\quad 81$
Annex 3.1 Ranks and Salary Scales $\quad 85$
Annex 3.2 Confidentiality 85 


\section{PART II COMPETITION POLICY IN PRACTICE}

4 Objectives and Strategies

A Community and National objectives 91

B Strategy: structure and behaviour 94

C Strategy: policy development and communication 96

5 The Treatment of Market Power
A Introduction
B The measurement of market shares
103
C The treatment of entry prospects
108
D Economies of scale and learning
E Brand loyalty and advertising
F Intellectual property rights

6 The Control of Mergers and Joint Ventures
A Introduction
B Jurisdiction and the selection of cases
C The treatment of horizontal mergers
D Vertical and conglomerate mergers
133
E Non-competition issues: management
135
$F$ Non-competition issues: gearing
$G$ Joint ventures

7 Pricing Policies
A Introduction
B Excessive pricing
C Parallel pricing
D Predatory pricing
E Pricing policies of public utilities

\section{Distribution}
A Introduction
B Restrictions as part of a commercial relationship
C Exclusive and selective distribution
172
D Exclusive dealing
176
E Full-line forcing and tie-in sales
178

\section{PART III THE IMPACT OF COMPETITION POLICY}

9 Trends: The Past and the Present 
B The development of policy 183

C The direct impact on industrial structure and business behaviour

D Transparency, consistency and efficiency

E Conclusions

10 The Future
A Introduction
207
B Restrictive practices
208

C Monopoly and competition inquiries

210

D Mergers policy

212

E Conclusions

214

List of Cases

References

223

Index 


\section{List of Tables}

1 Public interest criteria

2 Horizontal mergers found not against the public interest, 1979-88

3 Assessments of profits in reports of the Monopolies and Mergers Commission, 1978-87 


\section{Preface}

Those who are best qualified to write a book on this subject are far too busy to do so. Some of them have nevertheless been unstinting with their help and encouragement. Although I have relied throughout upon published material, the condensation which has been necessary to put it into an ordered and readable form raised serious dangers of inaccuracy, misinterpretation and false emphasis. Without help, it would have been rash for an outsider to attempt the task of providing businessmen with an insight into the inner workings of competition policy in Britain.

My heartfelt thanks go in particular to Martin Howe of the Office of Fair Trading and to Alan Blair and Noel Ing of the Monopolies and Mergers Commission for their painstaking and thoughtprovoking comments.

I have sought to inform rather than to criticise. The views and judgements which are nevertheless included are my own, and not those of the people who have helped me; and that, I am sure, will be true also of any errors.

Nick Gardner 